\title{
Editorial
}

\section{From Deficit to Surplus}

\author{
Barry Bracewell-Milnes, Banstead, United Kingdom
}

Most Member States of the European Union are at present struggling with difficult or even intractable problems of public finances in general, and budget deficits in particular. Few Member States are on course to satisfy the Maastricht criteria for a single currency. Government spending is hard to control and sometimes seems to have a life of its own. Tax buoyancy is depressed by taxpayer resistance at various levels and, in an increasingly mobile and electronic world, by the problem of applying traditional concepts such as permanent establishment and the difficulty of defining and providing who did what, where, when, in what status or capacity, and under whose tax jurisdiction. Over a longer time-scale, the net present values of unfunded or pay-as-you-go government pension liabilities in several major economies exceed (and thus effectively more than double) current levels of explicit or acknowledged government debt. In the United Kingdom, the generally satisfactory economic situation (rising output, low inflation) has not been reflected in the public finances, where the prospective deficit deteriorated between July 1995 and July 1996 by $£ 10$ billion, or well over 1 per cent of gross domestic product.

Events from less than ten years ago serve to put this gloom and doom into another perspective. Endemic crisis and perpetual semi-crisis are self-inflicted and are no more inevitable than desirable. In the late 1980s the United Kingdom Government deficit (public sector borrowing requirement) was falling as rapidly as it rose in the early 1990s. There was talk, optimistic but not at the time unrealistic, of abolishing income tax (not seriously considered for 150 years) or repaying the National Debt (not seriously considered for 300 years). Causes of tax buoyancy at that time can be identified as:

- fiscal drag - graduated tax schedules were applied to bases indexed at best for prices and not for earnings;

- the graduated schedule of corporation tax was unindexed for inflation and there was no indexation adjustment for stock relief;

- VAT was levied on luxuries, with their high income elasticity of demand, but not on necessaries, with their low income elasticity of demand;

- the VAT threshold was not indexed for earnings;

- the capital gains tax threshold was not indexed for prices;

- employers' national insurance contributions, with their weekly basis of charge, were not indexed to price or earnings within the year.

What went wrong? Why did the United Kingdom Government's finances deteriorate so drastically? The problem was partly that the economic boom was too rapid to last and had to be curtailed. But the main trouble was that effective constraints on the growth of government spending were relaxed or abandoned. For the year 1992/93, general government expenditure was planned to rise by 34 per cent from $£ 236$ billion in 1991/92 to $£ 317$ billion in $1996 / 97$. Few tax systems are buoyant enough to pay for spending increases of this order. The control of government spending is now an intractable problem throughout the industrialised world, and the endeavours of finance ministers may not achieve much unless they are reinforced by rules and institutions. Among the most versatile and successful rules for this purpose are cash limits on the spending of individual government departments; indexation of benefits to prices rather than earnings (United Kingdom state retirement pensions); and cash limitation of benefits, which exerts progressive pressure on the recipients as prices rise.

All this is important for taxation because tax reform is best achieved in a situation of revenue buoyancy. Fiscally neutral tax reforms, in which the gains of the gainers are matched by the losses of the losers, have the disadvantage that the losers feel their losses more keenly than the gainers feel their gains, with predictable political results. The satisfaction of the Maastricht criteria is not the only or perhaps even the most important reason for moving from government deficit to surplus: if the reality of tax reform is to match the challenges of a rapidly changing world, it should be part of a general tax reduction, which in turn requires tax buoyancy and falling budget deficits. 